\title{
A History of the Future: Time-Travel, Technology, Dystopia, and Postcolonial Anxiety in Vandana Singh's "Delhi"
}

Meera Vinod* and Gaana Jayagopalan ${ }^{\dagger}$

\section{Abstract}

The paper examines postcolonial concerns arising in and through the science fiction, "Delhi," by Vandana Singh as the author consciously deviates from generic conventions of the structures of Western science fiction. We argue that the protagonist in "Delhi" could be viewed as a postcolonial subject experiencing alienation and powerlessness. The character's postcolonial subjectivity is traced through Singh's manipulations of western science fiction tropes vis-à-vis time-travel, technology, dystopia, and narrative techniques. Using 'abrogation' and 'appropriation' (Ashcroft, Griffiths \& Tiffin, 1989), and Ricoeur's Time and Narrative (1988), the paper analyses how postcolonial elements are foregrounded. It also examines the larger implications of engaging in a postcolonial reading of a science fiction text produced from a technologically developing Indian context.

Keywords: Indian science fiction, Postcolonialism, Delhi, Timetravel, Technology, Dystopia, Appropriation

\section{Introduction}

'Who are we?' and 'What is the purpose of our existence?' These are two questions that are universal and timeless, and have

\footnotetext{
* The English and Foreign Languages University, meeravinlaks@gmail.com † CHRIST(Deemed to be University), Bengaluru, India; gaana.j@christuniversity.in
} 
plagued the minds of every self-aware human being. The disciplines of Science and Literature are both arguably conceived around these questions yet widely believed to be domains that are at complete loggerheads with each other. The genre of Science Fiction stands as a negation of this belief and an affirmation of the fact that scientific discovery and fiction are but two sides of the same coin. Both rely on a thorough understanding of how the world works, along with the ability to invent and discover alternative possibilities and explanations of everyday occurrences. When the two are combined, one discovers mutual influences that interact together to create new narrative techniques, fictional scenarios and moreover, inspire new ideas in science and technology. Hence, a new genre called Science Fiction with its own set of conventions is born. The genre is based on speculations of the future in terms of technological advancement, major social, and environmental changes, frequently portraying time travel or life on other planets.

Rob Latham in the Introduction to The Oxford Handbook of Science Fiction (2014) states that the problem for Science Fiction studies in its early history as an academic discipline essentially involved determining the nature and boundaries of its putative object and deciding what counts as Science Fiction (Latham, 2014). The overall thrust of this body of work was to argue for Science Fiction as a significant form of modern literature that raised consequential issues and intersected with major modes of criticism.

With reference to the Indian context, although Indian writing in English has always been considered a promising field of study in postcolonial discourses, the Indian Science Fiction genre has never managed to earn as much attention as it should have from literary scholars despite its subversive potential. In fact, it is only recently that postcolonial science fiction studies have gained prominence with the publication of anthologies such as So Long Been Dreaming: Postcolonial Visions of the Future edited by Nalo Hopkinson and Uppinder Mehan (2004), the scholarly works of Patricia Kerslake in Science Fiction and Empire (2007), and John Reider in Colonialism and the Emergence of Science Fiction (2008). In the anthology, So Long Been Dreaming: Postcolonial Visions of the Future, Nalo Hopkinson notes that heading off into the galaxy to colonise new worlds is often a 
theme of Science Fiction, "for many of us that's not a thrilling adventure story: it's non-fiction" (Hopkinson \& Mehan, 2004, p. 7). So why study this genre? Numerous critics have shown us how the tools of Science Fiction with its speculative outlook and subversive language and narrative make it possible for various alternative readings within the text-one of them, perhaps a very important one-- being the postcolonial reading.

Interestingly, however, Suparno Bannerjee in Postcoloniality, Science Fiction and India (2010) notes that these anthologies represent only a small proportion of Indian writers. A large part of the texts mentioned above come from the USA and Canada (written by Native Americans and Africans), rather than Asia or Africa. Additionally, Kerslake's work focusses on texts written by erstwhile colonisers rather than the colonised. Reider's anthology follows the same pattern. Nonetheless, we may safely admit that anthologies such as the ones mentioned earlier have begun the process of addressing issues that have required examination for a long time.

However, the aforementioned anthologies foreground only explicit postcolonial themes and concerns. A study undertaking how Western Science Fiction and Indian Science Fiction differ in terms of language, tropes and themes employed is required. The differences, if any, could shed light on how postcolonial concerns change the way Science Fiction is written. The paper also takes into concern the context in which Science Fiction is produced. Science Fiction as a genre often deals with ideas about the future, the consequences of technological change, and so on. Does India's present status as a technologically developing nation with a colonial past give rise to a different way of looking at these tropes? This paper seeks to add to the process of examining how Indian Science Fiction contributes to the field of Indian postcolonial studies through the specific narrative devices that the short fiction "Delhi" employs.

In this paper, we propose to examine "Delhi", a Science Fiction short story written by Vandana Singh. This paper can be read in the backdrop of how postcolonial elements work in Indian Science Fiction. In "Delhi," we argue that Aseem is positioned as an 
alienated postcolonial subject caught between fluxes of temporal changes in the city of Delhi. It is also explicated how this Indian Science Fiction text consciously deviates from Western generic conventions of writing Science Fiction in order to highlight postcolonial elements in constructing history, technology and time.

Thus, the objectives of this paper are:

1. To examine whether Singh writes in the Western tradition of Science Fiction writing and adheres to normative generic conventions

2. To examine how technology is represented in the story

3. To understand how the city as a space is represented and more specifically, how the historicity of Delhi as a city ties into the story as postcolonial Science Fiction, and

4. To understand the larger implications of writing Science Fiction as a genre that is not native to India, a postcolonial nation

The paper would employ a qualitative approach and engage in a textual analysis of "Delhi" by Vandana Singh to understand how the author uses certain narrative techniques to subvert the genre of Science Fiction so that postcolonial conflicts and ideas are brought to fore.

This paper would also engage with the idea of appropriation and abrogation as elucidated in The Empire Writes Back: Theory and Practice in Post-Colonial Literature by Bill Ashcroft, Gareth Griffiths and Hellen Tiffin (1989) ${ }^{1}$ in the context of Science Fiction. One of the crucial functions of language is its communicative function. However, there exists unequal power relations between different languages due to various reasons - one of them being colonialism. Hence, language can be understood as a site of power wherein one can find a register of canonical and normative usages deemed 'standard' and 'correct.' This demands that postcolonial writing defines itself by seizing the language of the centre and re-placing it in a discourse fully adapted to the colonised place. There are two distinct processes by which this can be achieved: abrogation and appropriation. Abrogation is the refusal of privileging the coloniser's language and using it in a 'correct' way, while 
appropriation is the process by which the coloniser's language is tailored to "bear the burden of one's own cultural experience" (Ashcroft, Griffiths \& Tiffin, 2002, p. 37). Both are an important means of decolonising language (2002).

While considering the intermingling of time with space and language in "Delhi," the paper engages with the central idea expounded in Paul Ricouer's Time and Narrative that explores the non-beingness of time. Time is understood as a consequence of language and hence subject to variance according to how a narrative is structured. Ricouer theorises that the world unfolded by a narrative work is always a temporal world. This means that time is understood as 'human time' to the extent that it is organised after the manner of narration. Similarly, narration is meaningful when it portrays features of temporal experience (Ricoeur, 1988). The interconnection of time and narrative is brought to the forefront in "Delhi" when the protagonist experiences time differently from the linear model of how human time is understood: past to present to future. Singh subverts this model by having the protagonist in the story travel back and forth between several timelines of the city's past, present and future. The subversion is significant as a means of articulating a rebellion against fixed and Westernised notions of how a fluid and conceptually difficult phenomenon like time is understood.

\section{2. "Delhi": An overview}

Vandana Singh's short story "Delhi" was first published in the anthology So Long Been Dreaming: Postcolonial Science Fiction and Fantasy (2004), edited by Nalo Hopkinson and Uppinder Mehan. The story is written in third person omniscient narration and features Aseem as a protagonist who can perceive Delhi at significant junctures of its past and future through time-travel. This confuses him greatly especially at instances when he encounters historically significant figures and feels compelled to interact with them in a bid to change the course of history. The confusion and anxiety lead him to attempt suicide but he is saved by an unknown person (implied to be his older self). This person directs him to 'Pandit Vidyanath', a mysterious being who claims to "work for the 
city" (Singh, 2004, para, 73). Aseem regards Pandit Vidyanath as a form of "mystic" technology entwined with the city itself. A person named Om Prakash acts as the mediator between Aseem and Vidyanath. Vidyanath (through Om Prakash) provides Aseem with a printed image of a woman who he claims would lend meaning to Aseem's life. Aseem undertakes the task to find the woman and searches for her even as he time-travels and interacts with various figures from the past and future, including kings, emperors and British officials. He calls these figures 'apparitions.' Finally, he meets the apparition of the woman who is supposed to be the key to his purpose in life. However, he is horrified to learn that she comes from a dystopian future of Delhi. She recedes away like most apparitions before he can learn more-all he knows is that the future of Delhi looks bleak. The existence of what the woman calls 'Neechi Delhi,' a part of the city for the poor and 'Naya Diwas lane,' a section for the rich, both angers and frightens him. He is also saddened at the anti-climatic meeting with the woman for whom he spent a considerable amount of time looking for. Om Prakash bears the brunt of Aseem's frustration as he tries to figure out what he can do to prevent the dark future ahead of him. This leads to questions about who Pandit Vidyanath is and what he stands for. Aseem is frustrated yet intrigued at his peculiar ability to travel between timelines. Thus, he sees overlapping visions of the past, present and future of the city and it seems that these visions are caused by the city itself. The city seems to Aseem like an entity with a mind of its own, controlled in some part by the unknown intelligence called Pandit Vidyanath.

Let us now turn to a reading of the protagonist Aseem as a postcolonial subject.

\section{Aseem as a postcolonial subject}

In the very first paragraph of the story, the reader is introduced to how carefully Aseem regards the city

Tonight he is intensely aware of the city: its ancient stones, the flat-roofed brick houses, threads of clotheslines, wet, bright colors waving like pennants, neem tree-lined roads choked with traffic. There's a 
bus going over the bridge under which he has chosen to sleep. The night smells of jasmine, and stale urine, and the dust of the cricket field on the other side of the road. A man is lighting a bidi near him: face lean, half in shadow, and he thinks he sees himself . . . He leaves the dubious shelter of the bridge, the quiet lane that runs under it, and makes his way through the litter and anemic streetlamps to the neon-bright highway. The new city is less confusing, he thinks; the colors are more solid, the lights dazzling, so he can't see the apparitions as clearly. But once he saw a milkman going past him on Shahjahan road, complete with humped white cow and tinkling bell. Under the stately, ancient trees that partly shaded the streetlamps, the milkman stopped to speak to his cow and faded into the dimness of twilight. (Singh, 2004, para, 1)

We see how Aseem is intensely aware of his location and associates all responsibility of his experiences towards the city. This is not surprising as the reader learns through the course of the story that Aseem is convinced that his time-travel condition is unique and limited to the city and more importantly, he develops the condition purely because of the city. After his encounter with the woman in the image and his subsequent knowledge of the fate of the city, he becomes defiant. He considers jumping into the river to see what causal effect this action would have on the future because he believes that the city has been playing a game with him and he has had enough of it. This is further depicted when we pay attention to the fact that whenever Aseem has an encounter with an apparition from another timeline, an extensive description of the city and its history ensues.

Similarly, he focusses on the city and its history as he remembers the interesting encounters he has had with the apparitions

He's seen more apparitions in the older parts of the city than anywhere else, and he's not sure why. There is plenty of history in Delhi, no doubt about that - the city's past goes back into myth, when the 
Pandava brothers of the epic Mahabharata first founded their fabled capital, Indraprastha, some three thousand years ago. In medieval times alone there were seven cities of Delhi, he remembers, from a well-thumbed history textbook - and the eighth city was established by the British during the days of the Raj. The city of the present day, the ninth, is the largest. Only for Aseem are the old cities of Delhi still alive, glimpsed like mysterious islands from a passing ship, but real, nevertheless. He wishes he could discuss his temporal visions with someone who would take him seriously and help him understand the nature and limits of his peculiar malady, but ironically, the only sympathetic person he's met who shares his condition happened to live in 1100 A.D. or thereabouts, the time of Prithviraj Chauhan, the last great Hindu ruler of Delhi. (Singh, 2004, para, 3)

Thus, we know that Aseem is always aware of his location and his position within the city. He regards his time-travelling ability as debilitating and often wishes for a kindred spirit to share the burden of knowing too much about one's future(s) and past(s). We can sense a certain amount of loneliness and inhibition in the protagonist as he travels through different realms in the city. Aseem's conceptualisation of Delhi's historicity is further significant from a postcolonial reading when we pay attention to how the city is described as an alien being.

The city's needs are alien, unfathomable. It is an entity in its own right, expanding every day, swallowing the surrounding countryside, crossing the Yamuna which was once its boundary, spawning satellite children, infant towns that it will ultimately devour. Now it is burrowing into the earth, and even later it will reach long fingers towards the stars. (Singh, 2004, para, 95)

Aseem's various trysts with historic colonial figures and their unawareness of the city's future pathways make Aseem regard the city as alien. His postcolonial subjectivity within the city and the 
narrative leads him to feeling alienated from the very location he is placed in and regards as home. Although the passage itself is aesthetically pleasing and may have a literary purpose, the fact is that Aseem likens the city to an alien complete with words like 'spawn', 'devour' and 'burrow', which is reflective of how he feels both as the dominant self in Delhi (with the city assuming the role of a menacing alien) and as an alien distanced from the city due to his time-travelling condition and the knowledge that comes along with it.

Aseem's feeling of alienation could also stem from the fact that similar to the manner in which Western Science Fiction posits an 'Other' within the text, there is a discourse of Hindu elitism present in many Indian science fiction texts which constructs identity through an opposition marked by the non-Hindu Other. In Other Tomorrows: Postcoloniality, Science Fiction and India, Suparno Bannerjee states that many Indian Science Fiction texts are entrenched with ideas of Vedic science and other similar ancient Indian traditions. This sort of an Indigenist discourse can be found in the works of Lakshman Londhe, J.V Narlikar, Chintamoni Deshmukh and Dattaprasad Dadbholkar (Bannerjee, 2010, p. 4). Therefore, Aseem being a Muslim (and this is understood not only because of his name but also his recollections of his grandmother's stories of Old Delhi, regarded as the 'Muslim part of Delhi' in the story) is significant wherein he occupies the position of the Other. The resulting anxiety because of his otherness is depicted in the way he associates Hindu mythology to the historicity of Delhi as something factual, and his offhand comment about the 'last great Hindu ruler', Prithviraj Chauhan.

Further, as quoted earlier, he associates the history of Delhi with that of myth and ties his knowledge of Delhi's history to Indraprastha and the Pandava brothers of the Mahabharata. He also mentions the seven cities of Delhi, during the medieval times, having gathered the knowledge from a "well-thumbed history textbook". (Singh, 2004, para, 3)

Aseem's ability to time-travel also makes him anxious about his position and power. He feels personally responsible for preventing or orchestrating events that happen in the future by trying to 
change the course of history, despite knowing very well that such actions are futile. Hence, his reaction to the feeling of powerlessness and guilt is to attempt to reclaim the power he loses because of his time-travelling condition by turning it to an advantage. This can be seen when he shouts out to the English about the impending doom of their empire, "Your people are doomed. You will leave here. Your Empire will crumble" (Singh, 2004, para, 10). However, they do not respond, other than being startled by his presence before fading away. Yet, in "his more fanciful moments," he wonders if he has managed to affect the British in some way or the other: "he wonders if he hasn't, caused history to happen the way it does...planted a seed of doubt in a British officer's mind about the permanency of the Empire" (Singh, 2004, para, 10).

Singh does not write the story simply as a subversion against a standard and official history of the city, but her manner of writing the story is a take on how Aseem's attempts to construct a particular narrative of history and his subsequent failure to do so result in a feeling of complete powerlessness. His attempts to turn away the English from their colonial overtures, his warnings to Mohammed Shah Rangila against Nadir Shah are met with complete refusal from these figures to heed these warnings. The refusals are sometimes delivered in a humiliating and derogatory manner.

Mohammad Shah Rangila, early 1700s, Aseem recalled. The Emperor who loved music, poetry, and wine more than anything, who ignored warnings that the Persian king was marching to Delhi with a vast army... "Listen, king," Aseem whispered urgently, wondering if he could change the course of history, "You must prepare for battle. Else Nadir Shah will overrun the city. Thousands will be butchered by his army ..."

The king lifted wine-darkened eyes. "Begone, wraith!" (Singh, 2004, para, 8-9)

The particular narratives of history that Aseem tries to construct are a direct result of his position as a postcolonial subject. His 
attempts to change the course of history seem innocuous to himself but it is clearly discernible that Aseem feels discomfited in the various colonial settings that he finds himself in. Thus, while it can be said that he actually does change a part of the narrative of history by simply witnessing it happen, his attempts to overtly change its course (again because of motivations that are an effect of his postcolonial position in the city) are largely futile. This resonates with his being an alienated postcolonial subject in the city. Aseem's continuous encounters and discomfiture with colonial figures point to his political, social, and emotional relationship with the colonial past. The persistence of this relationship in the present causes and draws upon deeply held fantasies, strong emotions, and intense belief systems. This feeling is magnified precisely because of his ability to actually interact with such a past, where otherwise a postcolonial subject would have merely imagined or felt one.

Aseem's reaction to his ability and his position as a character within a narrative that is frequented with breaks and disjoints ${ }^{2}$ is to try and regain the power he is losing because of the position he is in. Although from previous attempts, he knows that changing the course of history is futile, he still suffers from an anxiety of responsibility. This anxiety could also be read as a desperate attempt at trying to feel grandiose, in order to make up for his powerless position within the narrative.

Benedict Anderson in Imagined Communities: Reflections on the Origin and Spread of Nationalism theorises that postcolonial nations have to rely on "borrowing" modular imaginations of nationalism from the West as nationalism is itself a Western concept in origin and construct (Anderson, 1983). The proposition that a postcolonial subject can determine and construct their future is a fitting counter ${ }^{3}$ to the aforesaid statement. In "Delhi", Aseem is equipped with the ability to see into different time-continuums. Yet, he is not equipped to see every version of any given timeline. "One day, he tells himself, he will write a history of the future" (Singh, 2004, para 14).

Homi Bhabha talks of colonial anxiety in the form of hybridity which demonstrates how cultures come to be presented by 
processes of iteration and translation through which their meanings are vicariously addressed-through an Other. This is evident when Aseem understands Delhi's history through the presence of an Other - the Muslim rulers or the British soldiers. As cited below, the Hindu kings are seen as natural and therefore rightful in their presence in the city. However, after the entry of the Raj, the Muslims are seen as one with India, while the English are seen as the Other, through which Delhi derives its identity. This can be seen in the affectionate manner that Aseem describes Nai Sarak as "the heart of a crone who dreams perpetually of her youth" (Singh, 2004, para, 15). Although the word 'crone' may appear derogatory, the description is located right after he reminisces of memories with his grandmother and her stories of Nai Sarak. The description is punctuated with observations on "the blood and thunder of invasions, and the bodies of princes hanged by the British soldiers" (Singh, 2004, para, 15), thereby making a case against the British as perpetuators of violence.

By setting up a history of Delhi that posits a Self-Other relationship in terms of religion and location (Aseem as an Otherised postcolonial subject in a city he deems alien), Singh makes one wonder if a similar relationship exists in the dystopian future of Delhi, especially as the following quote is placed as a precursor to the part where the reader is introduced to the existence of the dystopian Delhi. "One of the things he likes about the city is how it breaks all rules. Delhi is a place of contradictions -it transcends thesis and anti-thesis. Here he has seen both the hovels of the poor and the opulent monstrosities of the rich" (Singh, 2004, para 40).

While the future Delhi with sky-towers seems quite ideal, it is betrayed by an underlying 'Neechi Delhi.' This goes on to speak a lot about the postcolonial subject itself. Hence the landscape of future Delhi is defined quite ontologically by a self/Other relationship in the form of the ideal Delhi ('Naya Diwas lane') and 'Neechi Delhi.'

\section{Dystopia and the self/other in "Delhi"}

There is a city below the city where the poor live. And above the ground is clean air and tall minars 
and udankhatolas that fly between worlds. No dirt or beggars or poor people. Like when the foreign VIPs come to town and the policemen chase people like me out of the main roads. But Neechi Dilli is like a prison, I'm sure of it. They can't see the sun. (Singh, 2004, para, 65)

The above quote shows how Aseem and the woman in the printed image understand the potentially dystopian future of Delhi in the form of structured binaries. Ideal Delhi occupies the privileged position in each binary mentioned, for example, it is above the ground, it is clean and it is rich, unlike 'Neechi Delhi.' Hence, a clear othering of 'Neechi Delhi' is seen. This enforced when the woman tells Aseem that 'Neechi Delhi' is like a prison. This means that 'Neechi Delhi' is associated with deviancy. The postcolonial reading of self/Other makes a prominent appearance in the way the characters in the story conceive of their position within a city that could head towards the final culmination of the ultimate realisation of a Self/Other through the creation of Ideal Delhi and 'Neechi Delhi.' Thus, the Self/Other relationship threatens to manifest itself quite literally in the form of Ideal Delhi and 'Neechi Delhi.' Aseem's anxiety as a postcolonial subject is thus physically depicted here.

Tom Shippey in "The History of Science Fiction" points out that despite "almost all definitions" of Science Fiction implying that the genre is "irrevocably committed to the future" (Shippey, 1981, 26), it can also be a literature which challenges history, decentering it, and rendering it critically contingent. "Delhi" reinforces this aspect of Science Fiction in its increased focus on the history of the city. In fact, the future is intrinsically connected to the history of the city itself: "One day, he tells himself, he will write a history of the future" (Singh, 2004, para, 14).

In a similar vein, Andy Sawyer in "Future History" argues that as writers began to conceive of the possible future as a venue both for genuine speculation about its nature and commentary upon the present, a sense that the future might have a history of its own developed (Sawyer, 2015). Aseem worries that the events of the city's history have paved way to its bleak future. It is significant to 
note that most of these events have a direct bearing on the effects of colonialism in the city. Thus, the future that Aseem encounters is almost an allegory of capitalism wherein the rich Delhi with its skyscrapping gemmed towers feeds off the dark underbelly that fuels that rich city. This underbelly called 'Neechi Delhi' is a miserable place for its inhabitants and they are prohibited from even accessing the other Delhi, known as 'Naya Diwas lane'. Capitalism and colonialism has always been connected, and hence, Aseem feels responsible for such a turn of events as he wonders, for instance, if he could ever have stopped the British Raj from their operations. This is again a reflection of Aseem's position within the text as a postcolonial subject.

\section{Time, narrative and alternate timelines}

Aseem's alienated postcolonial subjectivity can also be looked at as an effect of the temporal breaks in the narrative due to his timetravelling condition.

Paul Ricoeur in Time and Narrative explicates the "non-beingness" of time (Ricoeur, 1988). He emphasises the importance of language in understanding time. Hence, he says that in order for time to exist, there is also the need for narrative.

We recount things which we hold as true and we predict events which occur as we foresaw them. It is therefore still language, along with the experience and the action articulated language that holds firm in the face of the skeptics' assault (Ricoeur, 1988). This implies that how one's understanding of time and events in time is highly subjective and in variance with one's subjectivity with the world. A similar condition is seen in Aseem's understanding of how he experiences time-travel with a postcolonial subjectivity. His time-travelling is punctuated by significant colonial encounters. He is familiar with the colonial figures he encounters and their solidified position in history. Even then, he tries to change the course of history through his interactions with them. This would lead us to believe that Aseem understands time as subjective, which further indicates that the past really cannot be recalled 'truthfully.' This gives Singh the space to explore the subjectivity of 
power relations and historicity by using experimental narratives and temporal techniques in the plot. ${ }^{4}$

The passage of time in "Delhi" is skewered because of the subversive narrative techniques that Singh employs. Since time can only be understood in relation to narrative, it follows that disruptions in narrative can skewer temporality as well. Singh does this in a specific manner - her narrative structure in the manner of changing tenses, transliteration in significant places, non-linear narration point to a narrative experimentation seeking to foreground various postcolonial themes that affect both Aseem and the city.

Vandana Singh structures her narrative to include flashbacks where Aseem remembers his previous encounters with apparitions. Depending on the kind of flashback or encounter, the language that the story is written in changes accordingly. When Aseem recalls meeting Mohammed Shah Rangila, the writing takes on an archaic quality, with a transliterated couplet of a song of separation from one's beloved marking the end of the flashback. This technique calls the reader's attention to how fluid and ephemeral Aseem's reality is, along with the realisation of how time and language are constructs that keep changing. This is significant because rather than describing such a scene in the ordinary and functional prose that the narrator uses to describe Aseem's experiences, Singh chooses to incorporate transliteration as a means to signify how Aseem's temporality keeps shifting. Transliteration in itself can be viewed as a form of abrogation of the English language and Singh's usage of the same to showcase how Aseem experiences time also highlights a postcolonial concern on the constructs of how we write about history. Ricoeur talks of how language and narrative determines how we understand human time, and subsequently what we understand as 'truth.' Singh also plays with ideas of how notions of reality and history are viewed as truthful and objectivean issue that postcolonial studies tries to dismantle by bringing in 'unofficial' histories through the form of memoirs, recollections, stories, and so forth.

Vandana Singh's treatment of time in the story is interesting because we see that although she follows the Western mandated 
generic conventions of Science Fiction's ideas about time-travel, her treatment of this idea is vastly different. Aseem's time-travel is not fixed or unchanging. It is not as simple as travelling from the past to the future or vice-versa. Singh depicts the possibility of travelling between different timelines, and moreover, having absolutely no control of the destination. Further, she extends this premise by having other people from other timelines interact with Aseem in the form of apparitions. These people have no control of their time-travelling ability. Since Aseem is clearly experiencing his encounters with time-travel from a postcolonial internalisation of time and history, it is also possible that the other apparitions are experiencing the same condition.

He was walking past the faded white colonnades of some building in Connaught Place when he saw her: an old woman in a long skirt and shawl. . She put a wondering arm out toward him but didn't touch him. She said: "What age are you from?" in an unfamiliar dialect of Hindi. He did not know how to answer the question, or how to contain within him that sharp shock of joy. She, too, had looked across the barriers of time and glimpsed other people, other ages. She named Prithviraj Chauhan as her king. Aseem told her he lived some 900 years after Chauhan. They exchanged stories of other visionsshe had seen armies, spears flashing, and pale men with yellow beards, and a woman in a metal carriage, crying. He was able to interpret some of this for her before she began to fade away. He started toward her as though to step into her world, and ran right into a pillar. As he picked himself off the ground he heard derisive laughter. Under the arches a shoeshine boy and a man chewing betel leaf were staring at him, enjoying the show. (Singh, 2004, para, 4)

Hence, within the context of "Delhi" as an Indian postcolonial science fiction text, this becomes an allusion to the helplessness of Aseem (and the other apparitions) as a postcolonial subject who has absolutely no control over what timelines he would visit and 
who they would interact with. This feeling is heightened towards the part where he tries to follow the woman into "her world," but instead runs into a pillar, inviting laughter from some onlookers. Moreover, whenever he finds himself in the 'colonial past' quite literally, he realises that he has no control over the events that transpire. In the end, Aseem is forced to conclude that the city is a space to be reckoned with, something akin to a 'living entity' that controls itself and its subjects (Singh, 2004, para 94).

Matt Hills, in "Time, Possible Worlds and Counterfactuals," theorises that the prioritisation of time when thinking about Science Fiction's alternative versions of history can be traced to a specific moment of divergence from the actual history that underpins these fictions. The imaginative extrapolation of a path not taken can often be traced back to particular decisions or events in the diegetic world (Hills, 2015). This is seen in the story when every strand of history that Aseem encounters almost always has something to do with the effects of colonialism. In Aseem's anxiety to change the course of history, we can see the tensions of a colonial past manipulating his actions.

The implication is that at an infinite number of moments, time and history could have been otherwise. Science Fiction therefore does not restrict itself to imagining different outcomes for world historical events such as the Second World War, or different lives for the 'Great Men' of history. Massive shifts between narratives timelines can hinge on seemingly minuscule unimportant, almost meaningless actions and events. The democratising viewpoint is that history belongs to the unintended stumbling of ordinary, everyday life as much as it does to world politics (Hills, 2015). This is especially true of "Delhi" as Singh focusses on everyday events in Aseem's life with everyday people. His encounters with rulers or British soldiers have no effect on the timeline whatsoever but it is his meetings with ordinary and unknown people that change the course of history.

A closer look at how technology is portrayed in the story will help throw light on how Singh takes a major trope of Western science fiction writing and makes it unique to the Indian context. 


\section{Treatment of technology and science in "Delhi"}

The canon of Western Science Fiction has a number of texts that base their Science Fiction genre on their treatment and fictionalisation of technology. Singh incorporates this aspect of technology in her Science Fiction story as well but she does so by both subverting the kind of technology that exists in the text and appropriating what it means for the subjects within the text.

Suparno Bannerjee in Other Tomorrows: Postcoloniality, Science Fiction and India states that a specific dialect is seen in most Indian Science Fiction where techno-scientific rationalism is pitted against pre-industrial mysticism. This is manifested through different guises-programmatic societies, hybrid styles and technology or characters based on myth and folklore (Bannerjee, 2010). Pandit Vidyanath is one such hybrid technology that Singh employs to great effect in the text to create a sense of power and enigma that is associated with this character. In "Postcolonialism," Michelle Reid explains how the presence of Pandit Vidyanath as a form of Artificial Intelligence in the story can be associated with the Indian astrological traditions of 'Panditjis' trying to help people find a purpose in life and understand or 'predict' their future. Singh thus appropriates the European notions of science and technology and makes it native to Indian culture.

Reid states that "Delhi" is a hybrid form of postcolonial Science Fiction. She explains how the story uses representations of time and technology to question power relationships in India. For instance, the computer has been domesticated - produced by, and integrated into, Indian society to serve Indian culture (Reid, 2015).

Believing the promise that Pandit Vidyanath and Om Prakash would be able to help sort out Aseem's problems and give him purpose in life, after he spends the rest of his years in search of the woman who Om Prakash claimed would change his life. He maintains a notebook for chance encounters, always hoping that the next apparition would be the woman he is looking for. But, when he finally does chance upon her, their meeting is anticlimatic, and it leaves Aseem with bigger problems than he started with, such as the possibility of the city's dark and hellish future. When he approaches Om Prakash for help after his encounter with 
the woman and his vision of a dystopian Delhi, Om Prakash explains in very vague terms the science behind Aseem's visions and time-travel.

You can choose to break my bones, sir, and nobody can stop you. You can choose to jump into the Yamuna. Whatever you do affects the world in some small way. Sometimes the effect remains small, sometimes it grows and grows like a pipaltree. Causality, as we call it, is only a first-order effect. Second-order causal loops jump from time to time, as in your visions, sir. The future, Panditji says, is neither determined nor undetermined. (Singh, 2004, para, 70)

It leaves Aseem disillusioned with Pandit Vidyanath, and drives him to suicide again. Again, the narrative is repeated wherein another man (quite possibly, a future self of Aseem) prevents him from killing himself precisely in the same manner that the first man did. This leads Aseem to question whether Om Prakash and Pandit Vidyanath were what they seemed to be. Aseem rationalises everything by associating Pandit Vidyanath, whom he has come to understand as a form of unknown intelligence as an accomplice of the city. He speculates on the idea that the city itself could be a living being that controls him and everyone else for specific reasons.

This manner of thinking lends him some relief for he can seek closure from the bizarre events through this explanation. It has been established that the city is an important concern for Aseem and at a certain point he even regards it as a living alien entity. Therefore, it is significant that the only form of advanced technology found in the text is associated with the city (which heightens Aseem's postcolonial position in the narrative) and regarded as mythical and mystic more than scientific or rational. Hence, technology and artificial intelligence become an intrinsic part of the space that Singh foregrounds as mainly postcolonial than anything else.

We would also like to spend some time on the manner in which Om Prakash explains away Aseem's visions and time-travel. 
According to Om Prakash, Aseem's condition is a result of secondorder causal loops that jump from time to time. He rationalises this by stating that the future is neither determined nor undetermined. This explanation is legitimate within a scientific understanding of time-travel, causal loops and time paradoxes, frequently employed and fictionalised in Western Science Fiction.

However, Om Prakash chooses to reveal this fact to Aseem only towards the end of the story when Aseem is desperate to know whether he is a mere pawn in a pre-written history of the future. Yet, it is precisely Om Prakash, working through Pandit Vidyanath that gave Aseem the printed image of the woman who was supposed to give him a purpose in life. This indicates that the future already exists and Pandit Vidyanath is somehow aware of it. The instances where Aseem is saved by his future self also points towards this argument. Therefore, either Vidyanath or Om Prakash has lied to Aseem about the woman in the picture or they have lied to him about the truth of how his visions work. This would again point towards how technology and science is not represented in a good light in the text. They are seen as confusing and misleading to someone such as Aseem, who already experiences a great deal of trouble because of his visions and his abilities. At this point in the story, Singh's portrayal of the trope of technology as harmful and deceiving is an appropriation of western tropes of Science Fiction.

However towards the end of the story, Singh subverts such an understanding of technology again by revealing to the readers how Pandit Vidyanath actually 'works for the city.' Om Prakash reminds Aseem that he never claimed Pandit Vidyanath could change the future or even predict it. Their purpose was to help Aseem find a purpose in his life. While Aseem does not really understand what this means, we can see a sense of closure that Aseem feels with regards to this explanation. While he knows that Pandit Vidyanath and Om Prakash were not entirely truthful to him about the reality of his position in the city, he does not suspect them of foul play. Instead, he chooses to break the previous alliance he had with them and try to figure out answers for himself. Therefore, technology is seen as mysterious, and ironically illogical rather than the often-used western trope of technology being the reason for society's downfall. Further, Aseem relates the city's 
bleak and looming future to the city's history and the present disparity that could be seen between the poor and the rich in the city:

Delhi is a place of contradictions-it transcends thesis and anti-thesis. Here he has seen both the hovels of the poor and the opulent monstrosities of the rich. At major intersections, where the rich wait impatiently in their air-conditioned cars for the light to change, he's seen bone-thin waifs running from car to car, peddling glossy magazines like Vogue and Cosmopolitan. Amid the glitzy new high-rises are troupes of wandering cows, and pariah dogs; rhesus monkeys mate with abandon in the trees around Parliament House. (Singh, 2004, para, 40)

In the end, he resolves to look out for more people like him, people described as "poor," with "death in their eyes" (Singh, 2004, para, 94).

\section{Conclusion}

In conclusion, the paper has dealt with Singh's deviance from and willful appropriation of Western generic conventions of Science Fiction. She mixes technology with mysticism, time-travel with Hindu myths and disrupts time in the story through experimental narrative techniques. In "Delhi", the city is looked at as a living entity that consciously influences Aseem and furthers his doubts about his identity and position. Subsequently, the technology that is found in the story is one that is indigenised and domesticated. Hence, we can see how Singh does not limit herself to abrogating merely the language of Science Fiction writing. Rather, the narrative shifts, temporal breaks, stylistic inconsistencies, nonlinear plot and transliteration extend to the plot of the story itself. This means that rather than just the language, the generic conventions of Science Fiction is abrogated to showcase postcolonial elements at work.

We see how Aseem is positioned as an alienated postcolonial subject caught between the fluxes of temporal changes, and reflective narrative shifts in the city of Delhi. Thus, the Indian 
Science Fiction text works as a narrative that highlights postcolonial elements in constructing history, technology and time through its conscious deviation from Western generic conventions. These postcolonial elements are seen in every instance where Singh deviates from standard western generic conventions of Science Fiction writing. First is the use of the city as a space in which Aseem encounters significant colonial figures. It is the fact that Aseem believes he could possibly alter history which alerts us to how history is merely a construct, thereby, leading us to question and understand history from a postcolonial perspective, as Aseem does unconsciously. Second is the manner in which time functions and points to the faultiness of historiography, which leads to Aseem believing that he can alter the course of history, and feeling powerless when he cannot. Third is how technology is depicted wherein Pandit Vidyanath assumes a version of a hybrid domesticated and indigenised technology that Aseem associates with a mythical imagination than a rational or scientific one. We also saw how Singh has appropriated certain tropes of western Science Fiction such as technology and dystopia to give rise to postcolonial anxiety in the story.

As a result, Aseem as a protagonist is alienated from the city because of his position as a postcolonial subject able to travel between timelines that are historically significant to Delhi and witness colonial spaces and events yet unable to do anything about it. Aseem desires to undo certain events of colonial history yet he continuously fails to do so. Hence, Aseem's postcolonial anxiety is a direct result of how Singh manipulates her narrative to deviate from the tradition of how western science fiction is written vis-à-vis time, technology, tropes of dystopia, and indigenisation of language through transliteration and non-linear narratives.

Singh's conscious deviation and indigenisation of the genre could be viewed as an attempt to claim a voice and shape an image of India in the larger discourses of science and technology, of which India's position as a developing nation must depend on. Indian Science Fiction reveals the effect of globalisation and modernisation on the Indian identity.

It is all the more crucial to begin to engage with this body of work because, like the Western discourse on Indian history, Western 
discourses on India's future and technological potential could attempt to simplify, homogenise and codify the phenomenon in a formulaic manner. Indian Science Fiction however can subvert these attempts by challenging such codification and creating visions of alternative futures or tomorrows for themselves (Bannerjee, 2010). Indeed, this is reflected in the manner in which Western Science Fiction has started taking an interest in the discourse of future India because of the nation's increasing presence and importance internationally. However, a danger always lurks in such interests: in contrast to the manner in which India's future is portrayed by native authors, Western writers tend to revert to Orientalist stereotypes and provide a skewered image.

Hence, it is important to note how Singh subverts these tendencies by highlighting postcolonial issues in the genre itself by indigenising it to an extent. "Delhi" brings our attention to how a postcolonial reading of such a text underscores the discursivity of power and representation through colonial ideologies. The postcoloniality of Science Fiction can be seen as being inherent to the form owing to the "colonising" trope central to all Science Fiction works. The only difference is that Indian Science Fiction texts may actively work to bring out the "colonising" trope so as to make certain statements about power, representation and decolonisation.

\section{References}

Anderson, B. R. (1983). Imagined communities: reflections on the origin and spread of nationalism. London: Verso.

Ashcroft, B., Griffiths, G., \& Tiffin, H. (2002). The Empire writes back: theory and practice in Post-colonial literature ( $2^{\text {nd }}$ ed.). London: Routledge.

Banerjee, S. (2010). Other tomorrows: Postcoloniality, Science Fiction and India. Dissertation. Retrieved from LSU Digital Commons, (3181).

Bhabha, H. K. (2006). The location of culture. New York: Routledge.

Hills, M. (2015). Time, possible worlds, and counterfactuals. In Bould, M., Butler, A., Roberts, A., \& Vint, S., (Eds.), The Routledge Companion to Science Fiction, (pp. 432-433). London: Routledge.

Hopkinson, N., \& Mehan, U. (Eds.). (2004). So long been dreaming: Postcolonial Science Fiction \& Fantasy. Vancouver: Arsenal Pulp Press. 
Kerslake, P. (2007). Science fiction and empire. Liverpool Science Fiction Texts and Studies. Liverpool: Liverpool University Press.

Latham, R. (2014). The Oxford handbook of Science Fiction. New York: Oxford University Press.

McHale, B. (1987). Postmodernist fiction. London:Metheun.

Reid, M. (2015). Postcolonialism. In Bould, M., Butler, A., Roberts, A., \& Vint, S., (Eds.), The Routledge companion to science fiction, (pp. 256267). London: Routledge.

Reider, J. (2008). Colonialism and the emergence of Science Fiction. Middletown: Wesleyan University Press.

Ricoeur, P. (1988). Time and narrative (Vol. 1). (K. McLaughlin \& D.

Pellauer, Trans.) Chicago: University of Chicago Press. (Original work published 1984).

Sawyer, A. (2015). Future history. In Bould, M., Butler, A., Roberts, A., \& Vint, S., (Eds.), The Routledge companion to science fiction, (pp. 489494). London: Routledge.

Shippey, T. (1981). History in Science Fiction. In J. Clute \& P. Nicholls (Eds.), The encyclopedia of science fiction, (pp. 26). London: Orbit.

Singh, V. (2004). Delhi. Lightspeed: Science Fiction and Fantasy. Retrieved from www.lightspeedmagazine.com/fiction/delhi.

\section{End Notes}

1. Although the idea of Abrogation is usually only used in the context of language, one could also imagine how a literary form gets abrogated with multiple appropriations and breakage of conventions of genre until the form is unrecognisable. Since, "Delhi" is an Indian Science Fiction text that takes the western genre to highlight decidedly postcolonial concerns, one could say that a level of partial abrogation is taking place here.

2. The narrative is replete with breaks and disjoints as Aseem timetravels between locations and temporalities. Thus, the narrative is non-linear with flashbacks and flash-forwards in the form of visions.

3. Partha Chatterjee in Whose Imagined Community (1993) provides a counter argument to Anderson's theorization of postcolonial nations 'borrowing' modular imaginations of nationalism. He states that the nationalist imagination in Asia and Africa are premised on a difference from and not on an identity with western models of nationalism. 
4. Aside from the aforementioned temporal breaks, the language with which the text is written also changes along with narrative shifts. Hence, in an instance where Aseem encounters emperor Mohammed Shah, Singh includes a transliterated verse that the emperor sings. This could be significant as a manner in which Singh appropriates the genre through language itself, aside from generic techniques and structure. The paper has not gone into detail on this aspect. 